\section{A case of dyschondrosteosis from Roman Britain}

EDITOR-Dyschondrosteosis (Leri-Weill syndrome) is an autosomal dominant condition in which mesomelic short stature is associated with Madelung deformity of the radius. ${ }^{1-3}$ The expression of the condition is variable but consistently more severe in females and generally first appears in late childhood. ${ }^{4}$ Patients with dyschondrosteosis (DCS) have been found to have deletions and mutations of the short stature homeobox containing gene $(\mathrm{SHOX}) .^{35-9}$ Homozygous mutations at the DCS locus results in the more severe Langer type of mesomelic dwarfism. ${ }^{10}$

I report here a case of DCS discovered in a skeleton from the Romano-British period, which may be the earliest case known at present.

The skeleton was one of a small number of isolated burials excavated in 1998 from Crowland Road, Gloucester. The burials were in shallow graves, typically $0.4 \mathrm{~m}$ below the modern ground level and associated with structures dating to the 2 nd or 3 rd centuries AD. None of the burials was orientated west-east and therefore may be of pagan rather than Christian origin. Unfortunately the skeleton was damaged by earth moving equipment when the site was stripped and some further damage was sustained during excavation. Nevertheless, a photograph taken when the skeleton was still in situ clearly shows a Madelung deformity of the right forearm (fig 1).

During recovery, some of the bones were damaged so that the amount of the skeleton which was available for examination in the laboratory was less than shown in fig 1 . Nevertheless, it was clear that the skeleton was that of a robust male judging from the morphology of the pelvis and the skull. The left side of the skeleton had suffered particularly badly when the topsoil had been stripped off and only fragments of the left leg bones had survived. In addition, the left humerus had been broken and only a fragment of the left radius was recovered. Many of the vertebrae had been damaged when being removed from the soil and so had most of the proximal carpals, including the lunates, and some of the tarsals and other small bones of the hands and feet. The skull had been shattered but most of the individual elements seemed to be present.

The man was aged between 20 and 25 years of age at the time of death judging from the state of dental eruption, the morphology of the pubic symphysis, and the fact that the iliac crest and the clavicular epiphysis were still unfused.

The most significant abnormalities were Madelung deformity affecting the right radius (the only one which survived recovery sufficiently well for examination) (fig 2), an abnormal right humerus (fig 3), and mesomelia. The distal articulation of the radius was triangular rather than rectangular in shape and angled at approximately $45^{\circ}$ to the long axis of the bone and pointed medially and backwards, forming a $\mathrm{V}$ shaped articulation with the ulna for the carpal bones. Both ulnae were curved and substantially shorter than normal. The right humerus was considerably shorter than the left and the head was rotated medially and backwards by about $45^{\circ}$. The intact tibia was shorter than normal and a medial bony spicule was present on the proximal medial surface.

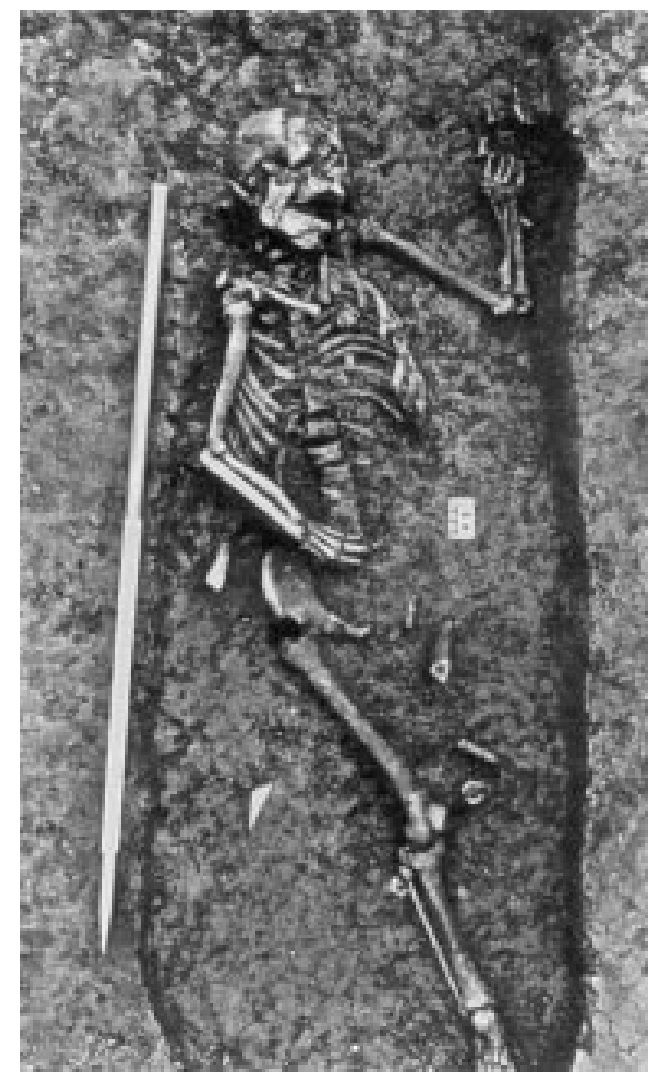

Figure 1 Photograph of skeleton of case of dyschondrosteosis in the ground showing a Madelung deformity of the right radius. Note that the body appears to have been put into the grave without care. Damage to the left leg was caused by earth moving equipment and further damage was caused during excavation. Marker is $1 \mathrm{~m}$ and arrowhead points north.

The lengths of the intact long bones and the estimated length of the left humerus are shown in table 1, with expected lengths for males from the Romano-British period. The length of the left humerus is very close to expected, but the right is clearly substantially shorter. The lengths of the radius and ulna are much shorter than expected and the right ulna is longer than the ipsilateral radius.

In the lower limb, although the right femur is substantially shorter than expected, the length of the ipsilateral tibia is relatively much shorter, showing the expected mesomelic impairment. The height of the man, calculated from the combined maximum lengths of the right femur and tibia was $1.56( \pm 0.3) \mathrm{m}$; for comparison, the mean height of males from a number of RomanoBritish contexts is 1.70 ( \pm 0.3 ) m (author's unpublished data).

An attempt was made to extract DNA from one of the vertebral bodies both to confirm the sex and to see if it was possible to carry out studies of SHOX mutations, but unfortunately no DNA had survived in this skeleton (GM Taylor, personal communication).

Examples of dwarfism are rarely encountered in human remains and the total number of reported cases is probably less than 20. The earliest known case seems to be that of an adolescent male from the Upper Palaeolithic in Italy, which was thought to represent acromesomelic dysplasia. ${ }^{11}$ Other cases include achondroplasia, cleidocranial dysostosis, 


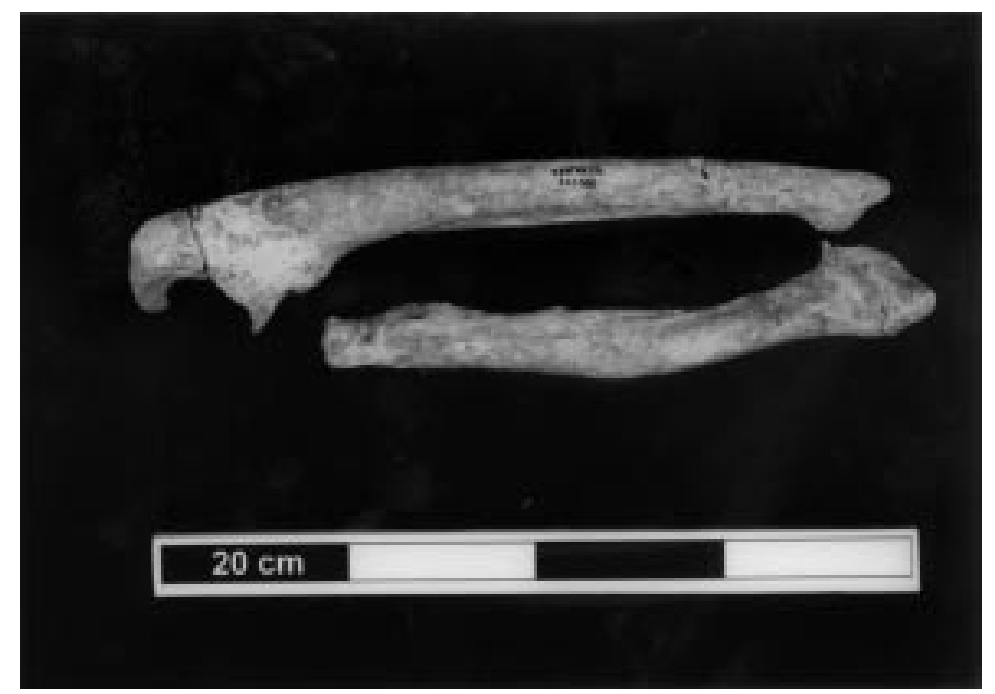

Figure 2 Right radius and ulna showing Madelung deformity and shortening of distal radioulnar joint. The head of the radius was lost during excavation and the postmortem break in the olecranon process has been repaired.

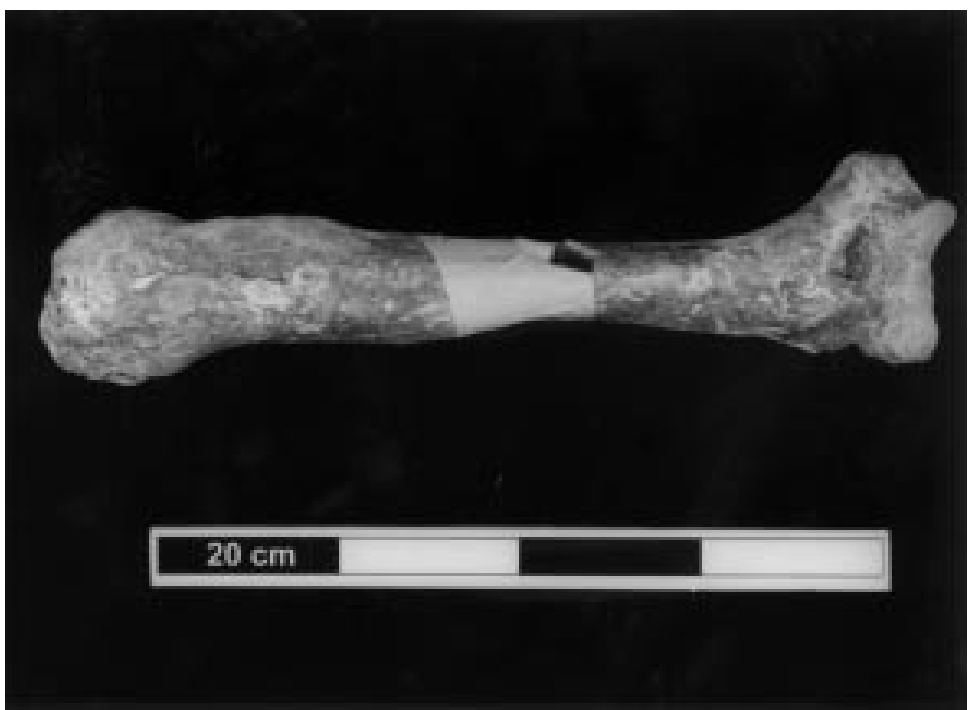

Figure 3 Right humerus showing shortening and abnormality of head. The postmortem break in the shaft has been repaired.

pituitary dwarfism, ${ }^{12}$ and two cases of spondyloepiphyseal dysplasia congenita with mild coxa vara from a Bronze Age site in Sweden which were thought to have been related. ${ }^{13}$ The present case is the first case of DCS to be described in archaeological material as far as I am aware.

Criteria for the classification of DCS have been published by a number of authors. Langer ${ }^{14}$ suggested that shortening of the radius, triangulation of the distal radial epiphysis, and wedging of the carpal bones were pathognomonic of Madelung deformity and he considered that Madelung deformity and DCS were the same condition. Other authors have added additional criteria for the diag-

Table 1 Lengths of long bones $(\mathrm{mm})$ from skeleton with dyschondrosteosis

\begin{tabular}{llll}
\hline Bone & $\begin{array}{l}\text { Observed } \\
\text { length }\end{array}$ & $\begin{array}{l}\text { Expected length } \\
\text { (SD) }\end{array}$ & Ratio O/E \\
\hline Left humerus & $310 \dagger$ & $327(17)$ & 0.95 \\
Right humerus & 246 & $333(19)$ & 0.74 \\
Right radius & 175 & $245(15)$ & 0.71 \\
Left ulna & 186 & $264(15)$ & 0.70 \\
Right ulna & 200 & $267(16)$ & 0.75 \\
Right femur & 413 & $456(25)$ & 0.91 \\
Right tibia & 302 & $366(25)$ & 0.83 \\
\hline
\end{tabular}

^Expected lengths based on observations from male skeletons from various Romano-British sites (author's unpublished data). †Estimated. nosis of DCS, however. ${ }^{215}{ }^{16}$ Mesomelia is a sine qua non of the condition and the shortening of the limbs is usually more extreme in the arms than in the legs. It is noted that the ulna is equal to or greater in length than the radius and that the fibula is equal to or shorter in length than the tibia. The present case meets many of the criteria necessary for the diagnosis of DCS although unfortunately many of the carpal bones were not recovered during the excavation and the fibulae were too damaged to be able to estimate their length relative to the tibiae. Given the changes in the distal articulation of the radius, it seems reasonable to suppose that the carpal bones would have been wedged between the abnormal articulation of the radius and the ulna as typically described. ${ }^{17}$ The changes in the humerus have occasionally been described in $\mathrm{DCS}^{18}$ and do not militate against the diagnosis. An exostosis on the proximal end of the tibia, such as was seen in this case, is another inconstant finding in $\mathrm{DCS}^{1}$ and spur formation may accompany other forms of mesomelic shortening of the upper limbs. ${ }^{19}$ Taken together, the morphological features of this skeleton seem adequately to confirm the diagnosis of DCS.

This man was in his late teens or early twenties when he died judging from the fact that the iliac crest was still fusing and that the clavicle was unfused. DCS is not known to 
be associated with premature death and several cases have been reported in adults. ${ }^{102021}$ There were no signs on the skeleton to suggest what the cause of death might have been, however, although this is, unfortunately, frequently the case when examining skeletal material.

The examination of human remains has relevance to clinical practice since it may provide new information about the pathology of a condition, as in the case of leprosy, for example. ${ }^{22}$ It may indicate ways in which the expression of a particular disease has changed over time and perhaps relate these to social or environmental factors, such as in osteoarthritis, ${ }^{23}$ or it may reveal clues to the antiquity of a disease within a population. The antiquity of the present case shows that the genotype necessary for the expression of DCS has been within the British population for not less than 1700 or 1800 years. The further study of human remains from other sites may show that its first appearance can be backdated even further.

I am grateful to the Cotswold Archaeological Trust for permission to publish this case and for providing me with fig 1 . I am also grateful to $\mathrm{Mr}$ Stuart Laidlaw for figs 2 and 3.

St Mary's Hospital, Praed Street, London W2 1NY, and Institute of Archaeology, University College London, London WC1H, UK

Correspondence to Dr Waldron, 31 Maidstone Road, London N11 2TR, UK, waldron@btinternet.com

1 Leri A, Weill J. Une affection congénitale et symétrique due développement osseux: la dyschondrostéose. Bull Mem Soc Med Hosp 1929;35:1491-4. 2 Sharif K, Saint-Martin C, Clapuyt P. Madulung deformity as a feature of the 292-3.

3 Spranger S, Schilller S, Jauch A, Wolff K, Rauterberg-Ruland I, Hager D, Tariverdian G, Troger J, Rappold G. Leri-Weill syndrome as part of a conTariverdian G, Troger J, Rappold G. Leri-Weill syndrome as part of
tiguous gene syndrome at Xp22.3. Am f Med Genet 1999;83:367-71.

tiguous gene syndrome at Xp22.3. Am f Med Genet 1999;83:367-71.
4 Lichtenstein JR, Sundaram M, Burdge R. Sex-influenced expression of Lichtenstein JR, Sundaram M, Burdge R. Sex-influenced expression of
Madelung's deformity in a family with dyschondrosteosis. $\mathcal{F}$ Med Genet 1980;17:41-3.
5 Rao E, Weiss B, Fukami M, Rump A, Niesler B, Mertz A, Muroya K, Binder G, Kirsch S, Winkelmann M, Nordsiek G, Heinrich U, Breuning $M H$, Ranke MB, Rosenthal A, Ogata T, Rappold GA. Pseudoautosomal deletions encompassing a novel homeobox gene cause growth failure in idiopathic short stature and Turner syndrome. Nat Genet 1997;16:54-63.

6 Belin V, Cusin V, Viot G, Girlich D, Toutain A, Moncla A, Vekemans M, Le Merrer M, Munnich A, Cormier-Daire V. SHOX mutations in dyschondrosteosis (Leri-Weill syndrome). Nat Genet 1998;19:67-9.

7 Shears DJ, Vassal HJ, Goodman FR, Palmer RW, Reardon W, Superti-Furga A, Scambler PJ, Winter RM. Mutation and deletion of the pseudoautosomal gene SHOX cause Leri-Weill dyschondrosteosis. Nat Genet 1998;19: 70-3.

8 Ogata T. SHOX: pseudoautosomal homeobox containing gene for short stature and dyschondrosteosis. Growth Horm IGF Res 1999;9(suppl B):53-7.

9 Cormier-Daire V, Belin V, Cusin V, Viot G, Girlich D, Toutain A, Moncla A, Vekemans M, Le Merrer M, Munnich A. SHOX gene mutations and deletions in dyschondrosteosis or Leri-Weill syndrome. Acta Paediatr Scand Suppl 1999;88:55-9.

10 Goldblatt J, Wallace C, Viljoen D, Beighton P. Heterozygous manifestations of Langer mesomelic dysplasia. Clin Genet 1987;31:19-24.

11 Frayer DW, Horton WA, Macchiarelli R, Mussi M. Dwarfism in an adolescent from the Italian late Upper Palaeolithic. Nature 1987;330:60-2.

12 Ortner DJ, Putschar WGJ. Identification of pathological conditions in human skeletal remains. Washington: Smithsonian Institution, 1981.

13 Arcinin C, Frolund P. Two dwarves from Sweden: a unique case. Int $\mathcal{F}$ Osteoarchaeol 1996;6:155-66.

14 Langer LO. Dyschondrosteosis, a hereditable bone dysplasia with characteristic roentgenographic features. AfR 1965;95:178-88.

15 Kaitila II, Leisti JT, Rimoin DL. Mesomelic skeletal dysplasias. Clin Orthop 1976;114:94-106.

16 Maroteaux P, Spranger J. Essai de classification des chondrodysplasies a predominance mesomelique. Arch Fr Pediatr 1977;34:945-58

17 Resnick D, Niwayama G. Diagnosis of bone and joint disorders. Philadelphia: WB Saunders, 1988.

18 Lamy M, Maroteaux P. Les chondrodystrophies genotypiques. Paris: L'Expansion Scientifique Français, 1960.

19 Kerner B, Rimoin DL, Lachman RS. Mesomelic shortening of the upper extremities with spur formation and cutaneous dimpling. Pediatr Radiol 1998;28:794-7.

20 Beals RK, Lovrien EW. Dyschondrosteosis and Madelung's deformity. Clin Orth 1976;116:24-8.

21 Mohan V, Gupta RP, Helmi K, Marklund T. Leri-Weill syndrome (dyschondrosteosis): a family study. F Hand Surg 1988;13:16-18.

22 Møller-Christensen V. New knowledge of leprosy through paleopathology. Int f Leprosy 1965;33:603-10.

23 Waldron T. Changes in the distribution of osteoarthritis over historical time. Int f Osteoarchaeol 1995;5:385-9. 